\title{
SWOT Analysis: Forest Engineering Course Diagnostic Tool
}

\author{
${ }^{1}$ Luis Fernando Fonseca Kasprzak, ${ }^{2}$ Ghislaine Miranda Bonduelle, ${ }^{3}$ Arnaud Francis Bonduelle, ${ }^{4}$ Umberto Klock \\ PhD Student, Federal University of Paraná, Postgraduate Program in Forest Engineering, UFPR, CEP 880210-170, Curitiba-PR, Brazil. \\ ${ }^{2}$ Professor, Federal University of Paraná, Postgraduate Program in Forest Engineering, UFPR, CEP 880210-170, Curitiba-PR, Brazil. \\ ${ }^{3}$ Professor, Technology in Quality Management, UFPR, CEP 81 520-260, Curitiba - PR, Brazil. \\ ${ }^{4}$ Professor (Coordinator), Federal University of Paraná, Postgraduate Program in Forest Engineering, CEP 880210-170, Curitiba - PR, Brazil.
}

\section{Correspondence Author:}

MSc. Luis Fernando Fonseca Kasprzak (PhD. Student). Universidade Federal do Paraná, Av. Pref. Lothário Meissner, 632, Jardim Botânico, Campus III, Curitiba PR, CEP 880210-170. Telefone: +55 (41)3271-1646.e-mail: luisfernando.fk@gmail.com

${ }^{2}$ Prof. $^{a}{ }^{D}{ }^{a}$ Ghislaine Miranda Bonduelle. Universidade Federal do Paraná, Av. Pref. Lothário Meissner, 632, Jardim Botânico, Campus III, Curitiba - PR, CEP 880210-170. Telefone: +55 (41) 33604212 e-mail: ghislainebonduellemiranda@gmail.com

${ }^{3}$ Prof. Dr. Arnaud Francis Bonduelle. Tecnologia em Gestão da Qualidade - UFPR, Rua Dr. Alcides Vieira Arcoverde, 1225, Jardim das Américas, Curitiba - PR, CEP 81520 - 260. Telefone: +55 (41) 3361-4916 e-mail: arnaud.bonduelle@ gmail.com

${ }^{4}$ Prof. Dr. Umberto Klock. Universidade Federal do Paraná, Av. Pref. Lothário Meissner, 632, Jardim Botânico, Campus III, Curitiba - PR, CEP 880210-170.

Telefone: +55 (41) 33604212 e-mail: klockuer@gmail.com

Received date: 15 April 2018, Accepted date: 15 June 2018, Online date: 5 July 2018

Copyright: $\odot 2018$ Luis Fernando Fonseca Kasprzak. This is an open-access article distributed under the terms of the Creative Commons Attribution License, which permits unrestricted use, distribution, and reproduction in any medium, provided the original author and source are credited.

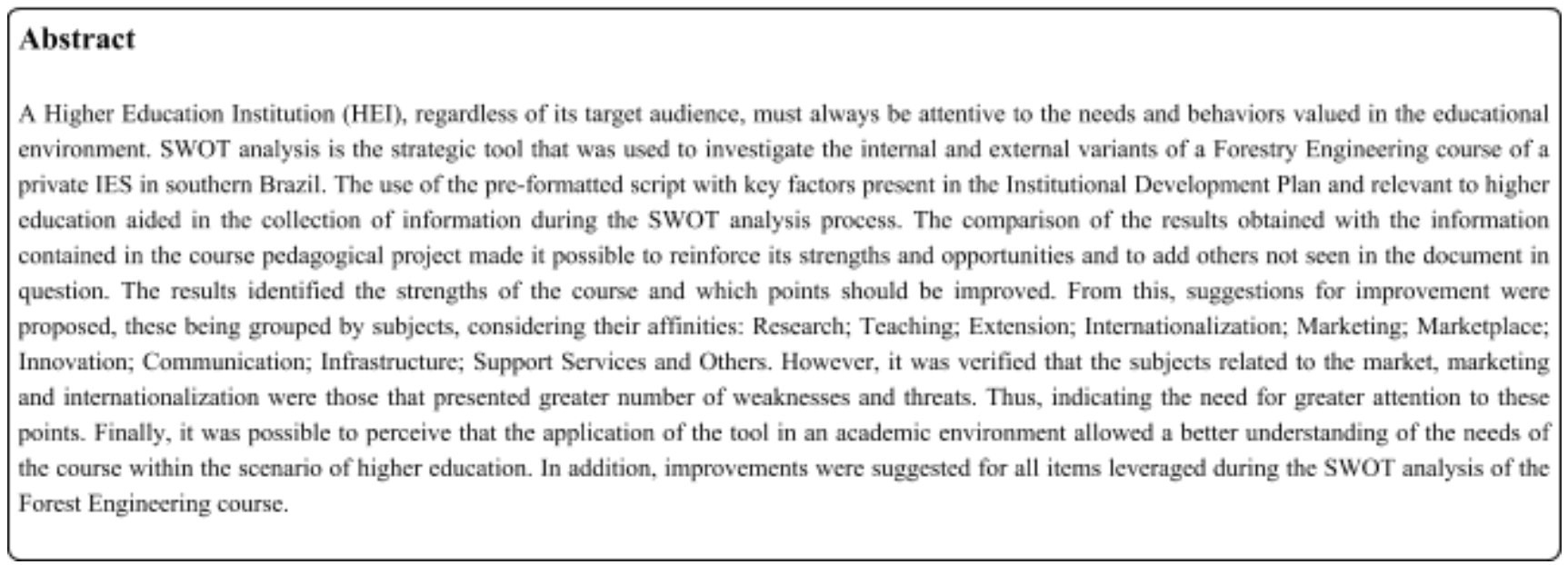

Key words: Higher Education, HEI, Internal and External Factors.

\section{INTRODUCTION}

In January 2018, 77 courses were registered in Forestry Engineering in Brazil, of which 03 are in extinction (E-MEC, 2017). In relation to September 2017, there was a reduction of 110 vacancies and, at the same time, an increase of 440 vacancies, totaling a further 330 vacancies. With respect to private HEIs, it was observed that 16 institutions offer 17 courses that are active and generate 1,875 authorized positions. Thus accounting for 400 more authorized places, an increase of $21.33 \%$ in six months. In the free HEIs there was an increase of 40 vacancies reaching 3,424.

To understand the analysis of the situation of a company in the context of the macro and micro environmental scenario, it is necessary the perception of scenarios and the study of the variables that can influence in the management of the company's processes. The careful analysis of a strategic tool in business planning that involves the approach of internal and external variants of the company is the SWOT analysis. The acronym SWOT means Strengths, Weaknesses, Opportunities and Threats.

According to Dyson (2002), it is an easy-to-use method that provides a transparent initial view and identifies problem areas. Strengths and weaknesses are determined by the company's current position and relate to internal factors. These are readings that help the company identify what is positive and reduce, through the application of an improvement plan, its weaknesses. The analysis of the 
Citation: Luis Fernando Fonseca Kasprzak, Ghislaine Miranda Bonduelle, Arnaud Francis Bonduelle, Umberto Klock.2018. SWOT Analysis: Forest Engineering Course Diagnostic Tool. Australian Journal of Basic and Applied Sciences, 12(7): 155-164. DOI: 10.22587/ajbas.2018.12.7.23

internal environment involves physical, human resources, facilities, location, products and services, logistics, operational and financial. Opportunities and threats are related to external factors and encompass the political, economic, social, technological and competitive environment, including the study of the market; of the demands of the period; of the highlights of other schools; and the comparison of the factors of relevance among HEIs.

In summary, the SWOT analysis contributes to the diagnosis of the key elements for the management of the company, implying the observation of the priorities of action to obtain strategic options in the observation of the risks and the problems that need to be solved. For it is through this that it is possible to understand the positives and the indication of which points should be improved, showing the chances of growth for increasing opportunities (Rauch, 2007).

The SWOT analysis is enshrined in the academic literature and is still applied by many authors (Dyson, 2004; Raant, 2007; Dantas, Melo, 2008; Dwivedi, Alavalapati, 2009; Scolozzi, et al., 2014). In the area of higher education the analysis of the environment of a university course can understand the study of the concurrent market; of the demands of the period; and the highlights of other IES courses. For, as LÜCK (2000) says, an HEI, regardless of its target audience must always be attentive to the needs and behaviors valued in the educational environment. Based on the context covered, the present study had the objective of applying the SWOT analysis in an undergraduate course in Forest Engineering in southern Brazil.

\section{MATERIALS AND METHODS}

The methodology includes the definition of internal factors (Strengths and Weaknesses); the definition of external factors (Threats and Opportunities); the classification of factors (SWOT Matrix); Creation of action and contingency plans; and the Analysis of results (LUZ, s / d) (Table 1).

Table 1. SWOT matrix model

\begin{tabular}{|c|c|}
\hline $\begin{array}{c}\text { Internal Analysis } \\
\text { "Organization" }\end{array}$ & STRENGHS (S) \\
\hline $\begin{array}{c}\text { External Analysis } \\
\text { "Environmental" }\end{array}$ & OPPORTUNITIES (0) \\
\hline
\end{tabular}

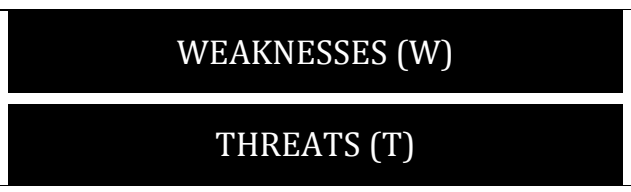

Source: ISO (2015).

In practice, the steps taken to apply the SWOT analysis essentially involved: the raising of ideas / items, filling dynamics and the classification of the information collected. In the phase of raising of ideas participated the teachers of the core structuring teacher and the coordination of the course. Aiming at consistency of participation, a facilitator was set to guide the dynamics and some guiding points were pre-defined to inspire debate and focus on the topic, and at the outset, the flow of ideas was free to avoid censorship or judgments and in the sequence a script was used by the mediator to raise questions and inspire the debate.

The analytical script (Table 2) with the items related to the analysis of internal factors (Strengths and Weaknesses) was constructed based on the educational principles of the Institutional Pedagogical Project (IPP), which is included in the Institutional Development Plan of the institution in question. The theoretical proposition based on the principles of the institution is an orientation of the Academic Dean for the elaboration of the Graduation Development Plan. The information of the script was also established from the results of studies carried out in the area, among them, the one produced by the Working Group (WG) for Quality Management in Higher Education of the University of Coimbra (2014) and the other one elaborated by Milan et al. (2014) that defined the quality attributes of the services provided by an HEI.

Table 2. Analytical script for analysis of internal factors.

Is the course perceived through the Marist, Christian and ethical values that transform society?

2.1 Professional Reputation of Faculty

2.1.2 Sufficient qualification against career requirements

2.1.3 Distribution of Teachers' Time Load

2.1.4 Alignment of teacher training with the area taught

Quality Perceived from the National Level Course

Perceived Quality of the International Level Course

Perceived quality of teaching (lesson plan, effective student work, activities between disciplines, etc.)

Tangible Heritage: Quality in Infrastructure (laboratories, classrooms, library, etc.)

Development of Researches in the area (publications and educational productions and students)

Academic Freedom: Students' Competencies / Autonomy

Course Learning Expectations

Profile of Higher Education 
157

Citation: Luis Fernando Fonseca Kasprzak, Ghislaine Miranda Bonduelle, Arnaud Francis Bonduelle, Umberto Klock.2018. SWOT Analysis: Forest Engineering

Course Diagnostic Tool. Australian Journal of Basic and Applied Sciences, 12(7): 155-164. DOI: 10.22587/ajbas.2018.12.7.23

Systematized Actions in Undergraduate: Teaching, Research and Extension

4.1 Teaching: Innovative actions for the practice of higher education

4.2 Research: Support and promotion of research projects

4.3 Extension: Diversity of Extension Proposals

Principles of Innovation in pedagogical practices, methodologies and use of technologies.

Development of activities that enhance and awaken, enhance and guide the entrepreneurial spirit.

Strategic actions with pedagogical alignment.

Disciplines with alignment in the profile formation of the egress.

Mobility to study subjects in other areas, schools, campus and among other institutions.

Communication between scientific areas.

Emphasis on curricular and pedagogical structure: Rationality of contents, workload and teaching staff.

Delivery of adequate value of the course that justifies the structure of the institution, the course and progress of the student.

Research for monitoring and analyzing employability.

Approach or strategies of partnerships with companies.

Diversity of Training profiles: offer of curricular internships and professionalizing character of the course.

Mapping and feedback of the graduates / employers.

Strategic alliances and partnerships with HEIs from other countries.

Disciplinary offer in a foreign language.

Course students who choose to take exchanges.

Foreign students who choose the course for exchange.

International student experience (technical visits, short and long courses).

Integrator Project (performance of common proposals between courses and disciplines).

Events for the visibility of the course, open to the community.

Promotion of assistive technologies for students with special needs.

Adequacy of the spaces in the Institution destined to the Higher Education of Forestry Engineering.

Course maturity: Resilience and adaptability in the face of dynamics.

Coordination model: Participatory and guiding principles.

Training offer for human capital requalification: Distance learning, post work regime.

Faculty facing new challenges.

Course actions that promote sports practice between teachers and students.

Course actions that promote the culture between teachers and students.

Intangible Heritage: Support of the course to the community (Community projects).

Relationship between teachers.

Rotativity of teachers.

Monthly value.

Location of HEI.

Knowledge of Internal Operations (dean, coordination, secretariat, academic management system.).

Teachers' Relation between students and collaborators.

Ability to attend to students.

Knowledge of managers on competition.

Source: The author based on Institutional Development Plan, Milan et al. (2014); Work Group of Quality Management in

Higher Education of the University of Coimbra (2014).

In the sequence, the most cited items were compiled and ranked according to the order of importance, thus identifying the factors that would compose the matrix. The classification used a qualitative scale of punctuation whose criteria result in a ranking of strengths or weaknesses and of threats and opportunities, demonstrating how much the factor impacts (Table 3). 
Citation: Luis Fernando Fonseca Kasprzak, Ghislaine Miranda Bonduelle, Arnaud Francis Bonduelle, Umberto Klock.2018. SWOT Analysis: Forest Engineering Course Diagnostic Tool. Australian Journal of Basic and Applied Sciences, 12(7): 155-164. DOI: 10.22587/ajbas.2018.12.7.23

Table 3. Parameters for analysis of internal and external factors

\begin{tabular}{|c|c|c|c|c|c|}
\hline Parameters for internal factors & & & Parameters for external factors & & \\
\hline Criteria & Score & Result & Criteria & Score & Result \\
\hline Does not attend - Insignificant & 0 & Neutral & Insignificant - Unfavorable & 0 & Neutral \\
\hline Does not attend - Important & -8 & Weakness & Insignificant - Neutral & 0 & Neutral \\
\hline Attend Reasonably - Insignificant & -5 & Weakness & Important - Unfavorable & -8 & Threat \\
\hline Attend Reasonably - Important & 2 & Strength & Important - Neutral & -2 & Threat \\
\hline Attends totally - important & 8 & Strength & Very Important - Neutral & -4 & Threat \\
\hline Attends totally - Very important & 10 & Strength & Very Important - Favorable & 10 & Opportunity \\
\hline
\end{tabular}

Source: Voitto (2017).

\section{RESULTS AND DISCUSSION}

The SWOT analysis was developed in November 2017 together with the teachers of the core structuring teacher and the coordination of the Forest Engineering course of a private university in the south of Brazil. The analysis considered the dimensions of the Institutional Development Plan and the results obtained in the analysis of the organizational context of the course were compared with the information that is present in the course pedagogical project of 2017 . With this comparison it was possible to verify a certain synergy between the two materials. Thus, observed points that were equal were maintained and different points that were pertinent were added, making the analysis complete. The Internal Factors: Strengths and Weaknesses; External Factors: Opportunities and Threats of the Forest Engineering course analyzed are presented in Table 4.

Table 4. Internal Factors: Strengths and Weaknesses; External Factors: Opportunities and Threats of the Forest Engineering course.

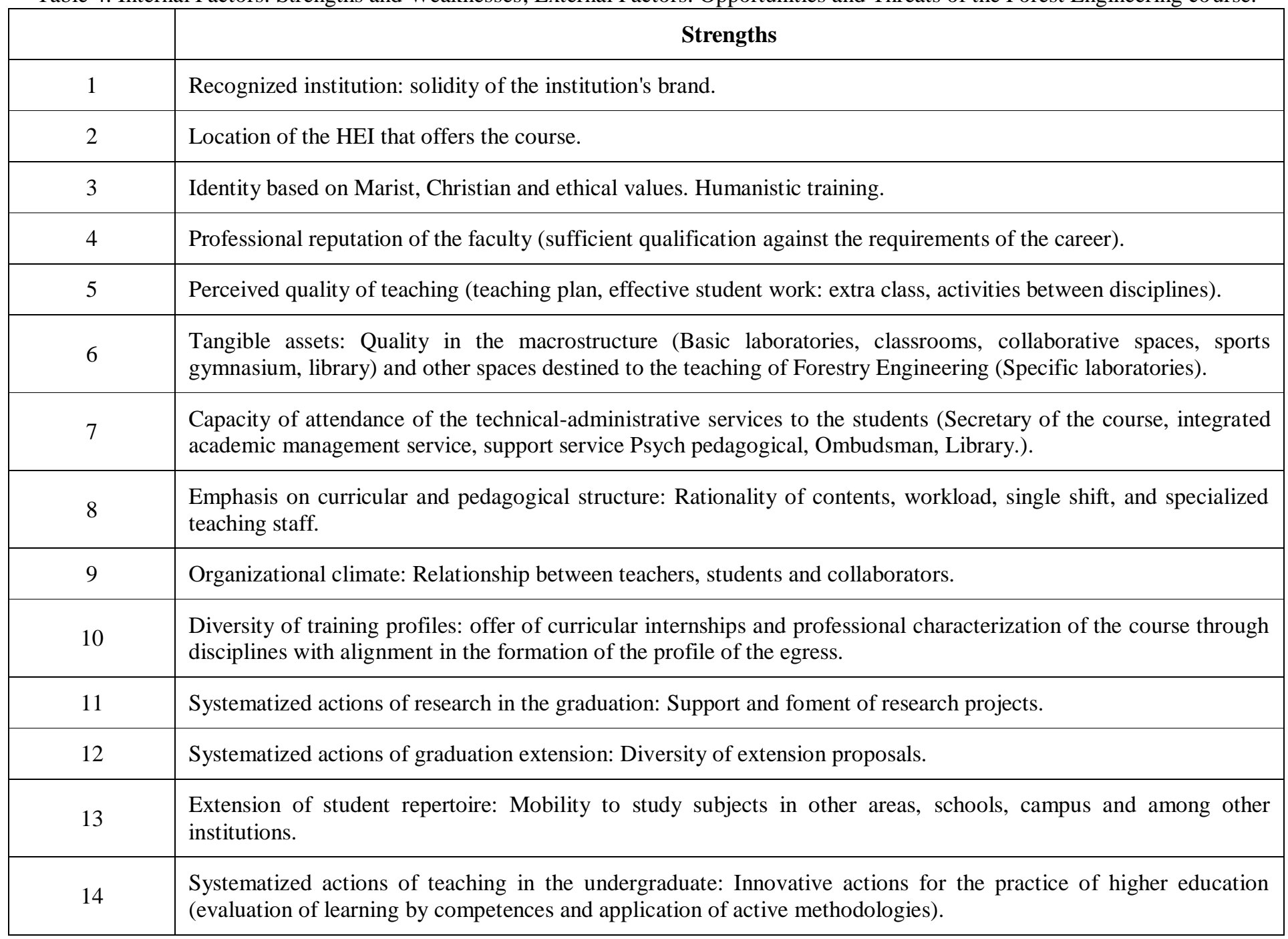


Citation: Luis Fernando Fonseca Kasprzak, Ghislaine Miranda Bonduelle, Arnaud Francis Bonduelle, Umberto Klock.2018. SWOT Analysis: Forest Engineering Course Diagnostic Tool. Australian Journal of Basic and Applied Sciences, 12(7): 155-164. DOI: 10.22587/ajbas.2018.12.7.23

\begin{tabular}{|c|c|}
\hline 15 & $\begin{array}{l}\text { Development of training activities that enhance, awaken and guide the entrepreneurial spirit, such as the Center for } \\
\text { Entrepreneurship and Opportunities, which serves to identify internship opportunities and actions to strengthen } \\
\text { strategic partnerships with companies. }\end{array}$ \\
\hline \multicolumn{2}{|c|}{ Weaknesses } \\
\hline 1 & The monthly fee is high. \\
\hline 2 & Lack of knowledge of the perceived quality of the course at the national level. \\
\hline 3 & Lack of knowledge of the perceived quality of the course at international level. \\
\hline 4 & Course maturity is low: Resilience and adaptability to dynamics. \\
\hline 5 & Little knowledge about the competition. \\
\hline 6 & Lack of approach or strategies of partnerships with companies. \\
\hline 7 & Strategic alliances and partnerships with HEIs from other countries are reduced. \\
\hline 8 & Training offer for the requalification of human capital is restricted: Distance learning, post-employment regime. \\
\hline 9 & There is no specific course offer in foreign language. \\
\hline 10 & Number of course students who choose to conduct interchange is null. \\
\hline 11 & Foreign students who choose the course for exchange are null. \\
\hline 12 & $\begin{array}{l}\text { International Student Experience (Technical Visits, short and long term courses, projects of attraction and retention } \\
\text { of students at home and abroad). }\end{array}$ \\
\hline 13 & Communication between scientific areas. \\
\hline 14 & Difficulty in accessing the information inherent to the course. \\
\hline 15 & The lack of a more focused dissemination for the course. \\
\hline 16 & Lack of research to monitor and analyze employability. \\
\hline 17 & Lack of Mapping and feedback of the graduates / Employers. \\
\hline 18 & Academic Freedom is restricted: Students' Competencies / Autonomy. \\
\hline 19 & Number of students enrolled in the course is low. \\
\hline \multicolumn{2}{|c|}{ Opportunities } \\
\hline 1 & Contribution of the forest sector to the Brazilian. \\
\hline 2 & Potentiality and growth expectations of the Brazilian Forestry sector. \\
\hline 3 & Development of innovation and technology in the field of Forestry Engineering. \\
\hline 4 & Available Forest Area Resources. \\
\hline 5 & Adequacy of standards and legislation. \\
\hline 6 & Promotion and actions supported by the area's regulatory council. \\
\hline 7 & Accelerators of Innovation in the forest area. \\
\hline 8 & Offer of research projects in technology and innovation in the field of Forestry Engineering. \\
\hline
\end{tabular}


Citation: Luis Fernando Fonseca Kasprzak, Ghislaine Miranda Bonduelle, Arnaud Francis Bonduelle, Umberto Klock.2018. SWOT Analysis: Forest Engineering Course Diagnostic Tool. Australian Journal of Basic and Applied Sciences, 12(7): 155-164. DOI: 10.22587/ajbas.2018.12.7.23

\begin{tabular}{|c|c|}
\hline 9 & Creation of strategic alliances of relevance to the forestry sector and organizations with investment interests. \\
\hline 10 & Utilization of the Experimental Farm as a research unit and for the development of strategic partnerships. \\
\hline 11 & Use of the wood laboratory to provide service. \\
\hline 12 & Valorization of environmental services (medium and long term). \\
\hline \multicolumn{2}{|c|}{ Threats } \\
\hline 1 & Reduction of government incentives (Funding for student). \\
\hline 2 & Political instability. \\
\hline 3 & Market situation (crisis / expansion). \\
\hline 4 & The market competition for graduates. \\
\hline 5 & Barriers to development. \\
\hline 6 & Lack of knowledge of the profession by society. \\
\hline 7 & Internationalization trend. \\
\hline 8 & $\begin{array}{l}\text { Absence of perception of the quality of the course / structure of the institution due to the lack of external } \\
\text { evaluations (National Student Performance Exam, Preliminary Course Concept, Student Guide). }\end{array}$ \\
\hline 9 & The number of regular internship vacancies. \\
\hline 10 & New course, little known by society. \\
\hline 11 & The number of competitors. \\
\hline 12 & The strength of competitors. \\
\hline
\end{tabular}

From the strengths (S) and weaknesses (W) and the threats (T) and opportunities (O) obtained during the SWOT dynamics, suggestions for improvement were proposed. Following, for a better organization, these suggestions were grouped by subjects, considering the affinities: Research; Teaching; Extension; Internationalization; Marketing; Marketplace; Innovation; Communic ation; Infrastructure; Support Services and Others. And so, a general goal was identified that addressed each subject group.

Subject 1: Research

- Increase the actions of scientific research in the academic environment;

W: Improving communication between scientific areas

- Encourage interaction between projects in related scientific areas to form groups and research strategies of the National Council for Scientific and Technological Development.

- Implement a group to disseminate and prospect the needs inherent in the area: innovation research, trends and future vision for the course.

O: Develop research projects in technology and innovation in the field of Forestry Engineering

- Create a committee of teachers to map proposals and real needs for research projects in line with market expectations, relevance and technical feasibility.

S: Expand the systematized actions of research in the undergraduate: Support and promotion of research projects.

- Idealize internal research center of the course to bring the teacher and student closer to the research standards and areas of development, in order to formalize knowledge in scientific production.

O: Available Forest Area Resources

- Identify bids for scientific research and extension projects in the forest area. To structure a nucleus of research, in order to technically subsidize the best use of governmental or private notices.

Subject 2: Extension

- Increase extension actions involving students and community;

S: Increase systematized extension actions in graduation: Diversity of extension proposals.

- Promote activities to extend the various areas of knowledge and segments close to Forest Engineering, with openness for 
Citation: Luis Fernando Fonseca Kasprzak, Ghislaine Miranda Bonduelle, Arnaud Francis Bonduelle, Umberto Klock.2018. SWOT Analysis: Forest Engineering Course Diagnostic Tool. Australian Journal of Basic and Applied Sciences, 12(7): 155-164. DOI: 10.22587/ajbas.2018.12.7.23

community participation and other students (lectures, round table, short courses).

Subject 3: Teaching

- Develop prospective actions for teaching

S: Improve the perceived quality of teaching (lesson plan, effective student work: extra class, activities between disciplines).

- Encourage and monitor the publication of information related to course discipline in the institution's digital platform.

S: Emphasize in the curricular and pedagogical structure the content rationality, workload, single shift and specialized teaching staff.

- To develop a periodic approach of the course subjects, of the contents programmed in the form of a timeline, in order to favor the student's knowledge with the future academic activities.

S: Diversify the training profiles: offer of curricular internships and the professionalizing character of the course through disciplines with alignment in the formation of the egress profile.

- To promote actions with professionals of the different areas of activity of the Forestry Engineer, to promote knowledge about professional practice.

S: Maintain the professional reputation of the faculty (sufficient qualification against the requirements of the career).

- Maintain teachers who present differentials in the curriculum and seek new ones with a reputation in the market, in order to promote the quality of the human capital of the course.

S: Reinforce identity based on Marist, Christian and ethical values. Humanistic training.

- Maintain the quality of Marist identity in the actions promoted by the course / school.

S: Expand the student repertoire: Mobility to study subjects in other areas, schools, campus and among other institutions.

- Encourage student participation through the dissemination of elective or elective courses with areas related to Forest Engineering.

S: To encourage systematized actions of teaching in the undergraduate: Innovative actions for the practice of higher education (evaluation of learning by competences and application of active methodologies).

- Implement actions aimed at improving the competency assessment system, with emphasis on providing training to teachers (Teaching activities workshop) and incorporating this system into assessments of the course subjects.

S: Increase the development of training activities that improve, awaken and guide the entrepreneurial spirit.

- Identify opportunities to enhance strategic partnerships with companies, through the Center for Entrepreneurship and Opportunities to promote internship activities and actions that may occur in conjunction with the disciplines.

W: Broadening Academic Freedom: Students' Competencies / Autonomy

- Establish orientation policies to promote practices of autonomy and sense-critical in the profile of the student.

Subject 4: Internationalization

- Promote internationalization actions in the course.

W: Offer specific subjects of the course in a foreign language.

- Improve new electives with a common approach to foreign language forestry issues.

$\mathrm{W}$ : Increase the number of course students in exchanges.

- Map foreign HEIs and consolidate partnership for students.

W: Foreign students who choose the course for exchange are null.

- Rank foreign HEIs and opportunistic strategic alliances.

W: International Student Experience (Technical Visits, Short and Long Courses, Projects of attraction and retention of national and foreign students).

- Consolidate partnerships with foreign HEIs and related areas to promote the international experience of students as hosts or course visitors.

W: Increase the knowledge of the quality Perceived of the course at the international level.

- Promote prospective actions with foreign HEIs for double diploma agreements. Provide the partnership of research projects in conjunction with foreign HEIs and publications in international journals, providing the visibility of the course.

$\mathrm{T}$ : Apply the internationalization trend.

- Develop academic mobility projects in partnership with other international HEIs and related areas to define challenges, materials and partners.... (Integrator Project with students from various areas to exchange and correlate experiences).

W: Strategic alliances and partnerships with HEIs from other countries are reduced.

- Promote prospective actions with foreign HEIs for double diploma agreements and exchanges for students (in / out).

Subject 5: Marketing

- Promote strategic marketing actions for the course.

S: Associate the course with the strength of the institution's brand.

- Create a graphic identity for the course and use it in conjunction with the institution's brand to strengthen this association.

W: To stimulate knowledge of the perceived quality of the course at a national level.

- Develop a plan for the dissemination of the course in national media and communication channels in the area.

W: Increase knowledge about the competition.

- Structure benchmarking plan through research and visits to national and international HEIs.

$\mathrm{W}$ : To promote the maturity of the Course through resilience and adaptability in the face of dynamics.

- Encourage direct marketing actions to nearby cities, or rural and forest regions to attract potential customers. 
Citation: Luis Fernando Fonseca Kasprzak, Ghislaine Miranda Bonduelle, Arnaud Francis Bonduelle, Umberto Klock.2018. SWOT Analysis: Forest Engineering Course Diagnostic Tool. Australian Journal of Basic and Applied Sciences, 12(7): 155-164. DOI: 10.22587/ajbas.2018.12.7.23

- Enable the opening of the course on campus off-campus, which is close to the agricultural and rural sector that already have the courses of Veterinary Medicine and Agronomy.

T: Contribute to the recognition of the profession by society.

- Plan events for the municipality of Curitiba and metropolitan regions, such as conferences and congresses to enable the profession's knowledge in the face of social trends and global sustainability. Promote institutional marketing actions with influential forestry companies, regional councils and media.

- To promote the perception of society on the importance of the professional of Forest Engineering.

W: Demand a more focused dissemination for the course.

- Consolidate and define, along with the communication area of the institution, the channels of dissemination and visibility for the course, as well as the information inherent to the course and the Forestry area.

$\mathrm{W}$ : Improve access to the information inherent in the course.

- Review the current architecture model of information related to the institutional website / web interface that designates the visualization of training schools, making it difficult to access the desired course.

T: To make the course known by society.

- Establish a marketing and publicity plan with the Institution's communication sector to reinforce the visibility of the course to society.

AM: Improve the perception of the quality of the course / structure of the institution through external evaluations (National Student

Performance Exam, Preliminary Course Concept, Student Guide).

- Structure internal campaigns with students about the need for academic spaces and laboratories for professional activities. Engage students with monthly meetings about the opinion about the course and subjects. Promote feedback on the institutional issues inherent to the student body.

\section{Subject 6: Market}

- Analyze and apply strategic market information for the improvement of the course.

- Implementing strategic partnerships.

$\mathrm{W}$ : Encourage rapprochement and create strategies for partnerships with companies.

- Develop proposals for the course in the action scenario, aiming at prospecting partnerships with companies in the sector.

W: Conduct mapping and feedback of graduated students / employers and graduated students.

- Map egresses to understand their market positioning and promote the relationship for future actions.

W: Apply research for follow-up and analysis of employability.

- Map and consolidate partnerships with companies to enable the appointment of graduates to professional attraction plans.

O: Contribution of the forest sector to the Brazilian.

- Identify strategic areas that contribute to the growth of the forest sector. Structure strategic plan to seek technical solutions associated with new processes and biotechnology through innovation research aimed at sustainable production.

O: Potentiality and growth expectations of the Brazilian Forestry sector.

- Structuring a plan for the approximation of professionals, organs and strategic companies, in order to promote forestry foresight through events, roundtables for discussions between teachers and students.

O: Enable the use of the Experimental Farm as a research unit and for the development of strategic partnerships.

- Structuring a partnership proposal to bring the reality of the market closer to the course through technical classes, in exchange the partner company guarantees visibility for the brand and future graduates who will perpetuate the knowledge acquired.

$\mathrm{T}$ : Analyze the number of competitors in the market.

- Map together with the core structuring teacher of the course and Marketing area of the Institution, the direct and indirect competitors. Select by type of university / institution and pricing scale.

$\mathrm{T}$ : Analyzing the strength of competitors.

- Planning Benchmarking: Road map of the Forestry Engineering coordination's of the national HEI to understand the differentials of each course: organization, subject areas, disciplines, faculty, geographic location, among others.

$\mathrm{T}$ : Encourage the increase in the number of regular internship vacancies.

- Create a direct line of contact with companies of internships and HR management of companies in the Forestry area and related with a responsible professor in the course, with the objective of mapping and consolidating partnerships to promote the nomination of students.

T: To analyze the political instability of the country and its consequences for the forest and educational market.

- Propose new educational product configurations to be offered to the market that adapt the needs to the new customer profiles.

T: Analyzing the market situation (crisis / expansion).

- Promote initiatives that generate results aimed at attracting stakeholders by reviewing the course portfolio, sector analysis / large areas of knowledge and predominance of the need for Forest Engineers in local rural regions and in global value chains.

- Formalize strategic alliances with companies and the regional Council of Engineering and Agronomy of Paraná.

T: Contributing to a more promising market for graduates.

- Provide visibility of the course completion work based on the premises that meets the market through feasibility and solution for forestry companies and technology incubators.

- Develop a course yearbook covering student projects in all periods for dissemination.

- Map the related areas and companies of the forestry sector to provide scenarios for the performance of the graduates in the market. 
Citation: Luis Fernando Fonseca Kasprzak, Ghislaine Miranda Bonduelle, Arnaud Francis Bonduelle, Umberto Klock.2018. SWOT Analysis: Forest Engineering Course Diagnostic Tool. Australian Journal of Basic and Applied Sciences, 12(7): 155-164. DOI: 10.22587/ajbas.2018.12.7.23

T: Monitor and analyze political instability.

- Propose new educational product configurations to be offered to the market that adapt the needs to the new customer profiles.

Subject 7: Innovation

- Implement in the course actions focused on innovation and technology.

O: Development of innovation and technology in the field of Forestry Engineering.

- To carry out integrative projects with related areas for the evolution of concepts of innovation and technology, in order to favor future scientific researches, publications in specialized magazines and to approach strategic alliances for the course.

O: Accelerators of Innovation in the forest area.

- Develop a plan to stimulate innovative projects, resulting from the disciplines of design and adapt the model for submission in innovation startups.

O: Create strategic alliances of relevance for the forestry sector and organizations with an investment interest.

- Map companies or agencies that develop innovation technology for the forestry sector, and create proposals to streamline the projects of this entity in the course, through targeted elective courses and innovation workshops.

T: To mitigate the impact of barriers to development.

- According to the Institutional Strategic Plan 2016-2022. Increase funding through sustainable businesses linked to innovation, entrepreneurship and service delivery.

T: Avoid reducing government incentives (Student Funding Fund).

- According to the Institutional Strategic Plan 2016-2022. Innovation in Graduation (Financier of Studies and Projects) - Produce innovations in teaching, evaluation and management of undergraduate courses that result in significant gains in learning and great competitive differential.

Subject 8: Communication

- Strengthen communication in the academic environment.

S: Organizational climate: Relationship between teachers, students and collaborators.

- Encourage communication, promoting objective and periodic meetings to enhance the synergy of those involved in the course.

Subject 9: Infrastructure

- Improve the infrastructure for the course.

S: Location of the HEI offering the course.

- Enhance the benefit of location and work the communication approach with the potential target audience.

S: Tangible assets: Quality in the macrostructure (basic laboratories, classrooms, collaborative spaces, sports gymnasium, library) and other spaces destined to the teaching of Forestry Engineering (Specific laboratories Farm area).

- Perform periodic maintenance and consider the results of the Evaluation committee that include evaluations regarding infrastructure for the improvement of spaces, through projects to obtain resources.

$\mathrm{O}$ : Enable the use of the wood laboratory to provide service.

- Develop a business model proposal to meet the external market, and companies that need reports. Consolidate the expertise of teachers for this demand.

Subject 9: Support services

- Improve Forest Engineering teaching support services.

S: Objective to excellence in the capacity of attendance of the technical-administrative services to the students (Secretary of the course, Integrated service of academic management, psycho-pedagogical service, customer complaints, library).

- Approach the technical administrative board of the information inherent to the course, based on the pedagogical didactic requirements, the curricular matrix and the training processes.

Subject 10: Other:

W: Propose a fair value for the course monthly fee.

- Justify through communication channels the added value of the course related to the infrastructure, such as the use of specific laboratories for student training.

W: Provide training offer for requalification of human capital: Distance learning, Post Work Regime.

- Enable internal training for teachers to develop human capital, seeking the maintenance of prestigious curricula.

W: Increase the number of students enrolled in the course (new entrants, transfers and / or reuse of course).

- Check which actions directly impact this weakness in order to make them feasible and monitor them.

O: Analyze the needs of adequacy of the norms and laws of the area.

- Formalize the training for the improvement of up-to-date information regarding current norms and legislation with the Area Council and bodies of interest.

O: Encourage participation in actions promoted and supported by the area's regulatory council.

- To bring the regulatory council of the area to the student for the diffusion of information of the profession, engagement with the market, in order to promote autonomy and the sense-critic.

O: Encourage the valuation of environmental services.

- Develop a plan for the environmental scenario, allowing development in services, new products (short courses and methodologies) 
for technical training in forestry.

\section{CONCLUSION}

The use of the pre-formatted script with key factors present in the Institutional Development Plan and relevant to higher education aided in the collection of information during the SWOT analysis process. The comparison of the results obtained with the information contained in the course pedagogical project made it possible to reinforce its strengths and opportunities and to add others not seen in the document in question. In addition, improvements were suggested for all items leveraged during the SWOT analysis of the Forest Engineering course. However, it was verified that the subjects related to the market, marketing and internationalization were those that presented greater number of weaknesses and threats. Thus, indicating the need for greater attention to these points. Finally, it was possible to perceive that the application of the tool in an academic environment allowed a better understanding of the needs of the course within the scenario of higher education.

\section{REFERENCES}

ABNT NBR ISO 9001: 2015, 2015. Quality Management Systems - Requirements. Brazilian Association of Technical Standards, Rio de Janeiro, RJ.

Dantas, N. G. S., R. S. MELO, 2008. The method of SWOT analysis as a tool to promote the tourist diagnosis of a place: the case of the municipality of Itabaiana / PB. Notebook Virtual Tour, 8(1): 118-130.

DwivedI, P., and J.R.R. ALAVALAPATI, 2009. Stakeholder's perceptions on forest biomass-based bioenergy development in the Southern US. Energy Policy, 37(2009): 1999-2007.

Dyson, R.G., 2004. Strategic development and SWOT analysis at the University of Warwick. European Journal of Operational Research, 152(2004): 631-640.

Lück, H., 2000. Application of strategic planning in school. Network Management Magazine, 1(19): 8-13.

Luz, 2017. Quick Guide: SWOT Analysis. Retrieved from https://blog.luz.vc/comofazer/ebook-guia-rapido-de-analise-swot/ on 19st August 2017

Milan, G. S., F. LARENTIS, A. CORSO, F. LAZZARI, and D. TONI, 2014. Attributes of the quality of the services provided by an HEI and the factors that impact on the satisfaction of the undergraduate students in administration. University Management Magazine in Latin America, 7(3): 291-312.

Rauch, P., 2007. SWOT analyses and SWOT strategy formulation for forest owner cooperation's in Austria. European Journal of Forest Research, 126(3): 413-420.

Scolozzi, R., U. SCHIRPKE, E. MORRI, D. D’AMATO, and R. SANTOLINI, 2014. Ecosystem services-based SWOT analysis of proteted areas for conservation strategies. Journal of enviromental management, 146: 543-551.

Sectorial Commission For Education And Training., Work Group For Quality Management In Higher Education, 2014. SWOT Analysis of Portuguese Higher Education: opportunities, challenges and quality strategies. Retrieved from http://hdl.handle.net/10316.2/33292/ on 4st March 2018

Voitto, 2017. Do your SWOT analysis in Excel. Retrieved from http://www.voitto.com.br/blog/artigo/analise-swot-excel/ on 10st October 2017

E-MEC, 2017. Institutions of higher education and registered courses. Retrieved from http://emec.mec.gov.br/ on 10 st August 2017 